Функціонування запропонованої моделі припускає реалізації комплексу взаємопов'язаних педагогічних умов. Ідеться, зокрема, про створення освітньо-виховного середовища в медичному коледжі; формування мотиваційно-ціннісного ставлення до майбутньої професії; збагачення змісту навчальних дисциплін, виховних заходів, виробничої практики завданнями професійно-етичного спрямування. Педагогічна дія викладачів забезпечує послідовне дотримання зазначених педагогічних умов і спрямовується на виконання педагогічної взаємодії 3 майбутніми молодшими спеціалістами сестринської справи.

Отже, в умовах сьогодення зростають вимоги до таких професійно-етичних якостей майбутніх медичних сестер, як: висока моральність, здатність до емпатії, добропорядність, готовність завжди прийти на допомогу. Здійснений аналіз переконує: процес формування професійної етики у майбутніх медичних сестер буде більш успішним, якщо враховувати компетентнісний, культурологічний, аксіологічний підходи. Так, відповідно до компетентнісного підходу, навчання доцільно спрямувати на формування професійно-етичних умінь; культурологічний підхід дозволяє створити оптимальні умови засвоєння загальнолюдської й національної культури; аксіологічний підхід застосовується задля усвідомлення та самореалізації особистістю своїх культурних потреб, інтересів і здібностей, виховання цінностей майбутньої професії.

У подальших публікаціях маємо на меті подати дослідно-експериментальну перевірку структурно-змістової моделі формування професійної етики майбутніх медичних сестер у медичному коледжі з урахуванням зазначених вище підходів.

\title{
Література
}

1. Беденко-Зваридчук О. Культура поведінки та етика взаємовідносин у роботі медичної сестри / О. Беденко-Зваридчук // Журнал головної медичної сестри. - 2012.- № 2 / жовтень / [Електронний ресурс _ - Режим доступу: http://medprosvita.com.ua/kultura_povedinki_ta_etika_vza $\%$ D1\%94movidnosin_u_roboti_medichnoji_sestri - Загол. 3 екрану. - Мова польська. 2. Гончаренко С. У. Український педагогічний енциклопедичний словник / С. У. Гончаренко. - Рівне : Волинські обереги, 2011. - 550 с. 3. Зязюн І. А. Філософія поступу і прогнозу освітньої системи / I. А. Зязюн // Педагогічна майстерність: проблеми, пошуки, перспективи: [монографія]. - К.; Глухів : РВВ ГДПУ, 2005. - С. 10 - 18. 4. Каган М. С. Философская теория ценности / М. С. Каган. - С-Пб., 1997. - 205 с. 5. Компетентнісний підхід у сучасній освіті: світовий досвід та українські перспективи: Бібліотека з освітньої політики ; під заг. ред. О. В. Овчарук. - К. : «К.І.С.», 2004. - 90 с. 6. Офіційний сайт ЮНЕСКО : збірка документів. - [Online]. Режим доступу: http: http://aidden.hut/ru.index. 7. Хуторской А. В. Предметное и общепредметное в образовательных стандартах / А. В. Хуторской, А. В. Краевский // Педагогика. - 2003. - № 3. - С. 3-10. 8. Fabre Aurelien Pedajojie scientinque et education / Par Aurelion Fabre. - Parise: Libr., Colin, 1978. - 159 p.

Світлана Луценко

\section{ВИКОРИСТАННЯ МОЖЛИВОСТЕЙ ІНФОРМАЦІЙНИХ ТЕХНОЛОГІЙ В ІННОВАЦІЙНОМУ УПРАВЛІННІ ОСВІТОЮ}

Луценко С. М. Використання можливостей інформаційних технологій в інноваційному управлінні освітою.

У статті розглядаються проблеми запровадження інформаційної системи управління освітою. Звернено увагу на специфіку взаємодії органів місцевого самоврядування, відділів освіти та навчальних закладів при застосуванні ІСУО в Сумській області.

Ключові слова: інформаційні технології, інформаційна система управління освітою, єдине інформаційно-освітнє середовище.

Луценко С. М. Использование возможностей информационных технологий в инновационном управлении образованием.

В статье рассматриваются проблемы внедрения информационной системы управления образованием. Обращено внимание на специфику взаимодействия органов местного самоуправления, отделов образования и учебных заведений во время внедрения ИСУО в Сумской области.

Ключевые слова: информационные технологии, информационная система управления образованием, единое информационно-образовательную среду. 
Lutsenko S. N. Harnessing the power of information technology in innovative management education.

In article consider the problems of implementing management to information system education. Attention is focused on the interaction between local governments, education departments and schools when applying Education Management Information System in Sumy region.

Key words: information technology, management information system education, informationeducational environment.

Проблема управління є проблемою загальнонауковою, оскільки це предмет досліджень багатьох наук: менеджменту, економіки, соціології, юриспруденції, психології тощо. У широкому розумінні поняття «управління» визначають як елемент, функцію організованих систем, різних за природою (біологічних, соціальних, технічних), що забезпечують збереження їх відповідної структури, підтримують режим діяльності та реалізацію їх програм. У контексті управління навчальними закладами такий феномен розглядають через методи і діяльність із забезпечення вимог якості освіти. Саме цим зумовлене виникнення в педагогіці нових напрямів - педагогічної інноватики та IT-освіти, які стали соціальними галузями наукового пізнання, що характеризується певним змістом, принципами, тенденціями та закономірностями розвитку

Ефективність інформатизації управління освітою значною мірою залежить від наукового обгрунтування цього процесу. Проблемами управління загальноосвітніми навчальними закладами з урахуванням соціальних, економічних, політичних перетворень займаються такі науковці В. Бегей, В. Бондар, Л. Даниленко, Г. Сльнікова, Н. Островерхова та інші. Питання створення IT-баз даних у системі управління навчальними закладами розкриваються у працях В. Бикова, В. Руденка та ін.

Mета статmi - розглянути особливості запровадження педагогічних інновацій через реалізацію ідеї інформаційно-комунікаційної освіти та інформаційного управління освіти.

Складність, багатоаспектність і взаємозалежність управлінських проблем у період розбудови школи потребують нових ідей і підходів, що розвивають перспективи пошуку оптимальних інновацій управлінської діяльності.

Основну відмінність між загальною системою управління та інноваційною системою управління освіти науковці вбачають у тому, що остання полягає у встановленні та використанні всіма суб'єктами освіти пріоритетів якості: якості умов, якості процесу та якості результатів цього процесу [8].

Під терміном «інновація» - ми розуміємо нововведення, цілеспрямовану зміну, яка викликає перехід системи 3 одного стану до іншого. Інноваційна управлінська діяльність відповідає процесам внесення якісно нових елементів до освітнього менеджменту.

Поняття «технології» в педагогічних дослідженнях має різні визначення. Виходячи 3 етимології слова (з грец. techne - мистецтво, майстерність, уміння i logos - слово, учіння), поняття «технологія управління» ми визначаємо як цілісний процес управління освітою. [9].

У сукупності управлінських інновацій, що впроваджуються у навчальних закладах, виокремлються: модернізовані зміст, форми й методи управлінської діяльності керівника школи, громадсько-державні, регіональні, модульні, проектні моделі управління. До управлінських інновацій слід віднести сучасні економічні, психологічні, діагностувальні, інформаційні технології, які дають змогу створити відповідні умови для оперативного й ефективного прийняття керівником управлінського рішення. Практика педагогічної діяльності свідчить, що саме колектив навчального закладу на чолі з керівником має визначитись, які це будуть зміни за інноваційним потенціалом, на що вони спрямовані, чи забезпечать ефективний розвиток закладу.

У сучасних умовах демократизації суспільства, зміни структури й змісту освіти, іiі гуманізації й гуманітаризації особливого значення набуває питання підготовки людини до повноцінного життя в інформаційному суспільстві. Останнє десятиріччя XX-початок XXI століття, характеризується низкою кардинальних політичних, економічних, структурних та інших змін у світі. Серед них $є$ одна принципова структурна зміна в сучасному суспільстві, що полягає у стрімкому за темпами й глобальному за масштабами переході від індустріального суспільства до інформаційного [3]. Інформаційне суспільство, у свою чергу, ставить нові цілі і завдання, зокрема - автоматизацію всіх процесів, 3 метою оптимізації та раціоналізації діяльності суспільства. 
Інформаційно-комунікаційні технології поступово, активно і невпинно інтегруються до усіх галузей діяльності людини і суспільства, стають могутнім каталізатором і визначальним джерелом їх об'єктивного розвитку. Цей процес називають інформатизацією суспільства, а саме суспільство набуває ознак інформаційного.

«Інформатизація - це сукупність взаємопов'язаних організаційних, правових, політичних, соціально-економічних, науково-технічних, виробничих процесів, спрямованих на задоволення інформаційних потреб, реалізацію прав громадян і суспільства на основі створення, розвитку, використання інформаційних систем, мереж, ресурсів та інформаційних технологій, побудованих на основі застосування сучасної обчислювальної та комунікаційної техніки» [5].

Інформатизація науки, освіти й культури - один 3 основних напрямів інформатизації суспільства і головна умова, що визначає розвиток цих галузей. У «Концепції Національної програми інформатизації» подане визначення інформатизації системи освіти: «Інформатизація системи освіти- це упорядкована сукупність взаємопов'язаних організаційно-правових, соціально-економічних, навчально-методичних, науково-технічних, виробничих й управлінських процесів. спрямованих на задоволення освітніх інформаційних, обчислювальних i телекомунікаційних потреб учасників навчально-виховного процесу; на формування та розвиток інтелектуального потенціалу нації; удосконалення форм і змісту навчально-виховного процесу шляхом упровадження комп'ютерних методів навчання й тестування» [7].

Інформатизація навчальних закладів передбачає упровадження інформаційно-комунікаційних процесів і технологій, що забезпечують інформаційні потреби всіх учасників освітніх процесів як у конкретному закладі освіти, так і в системі освіти взагалі. Соціальні інформаційнокомунікаційні технології сьогодні відіграють визначальну роль у забезпеченні взаємодії між людьми, у підготовці та розповсюдженні масової інформації, подальшому розвитку культури, освіти, науки. Підвищення сучасного рівня системи загальної середньої освіти неможливе без формування національного науково-освітнього інформаційного середовища.

Інформаційно-комунікаційна технологія управління закладом освіти $\epsilon$ педагогічною технологією, що визначається як система спільної діяльності педагогічних працівників закладу освіти, учнів та їх батьків, реалізацію якої спрямовано на управління плануванням, організацією, контролем, коригуванням і створенням комфортних умов навчально-виховного процесу з метою досягнення визначеного конкретного результату [7].

Використання інформаційно-комунікаційних технологій в управлінні освітою $\epsilon$ складником розвитку єдиного інформаційного середовища. Без чіткої організації роботи центрального органу системи управління освітою неможливо організувати управління всією системою в цілому. Для створення єдиної освітньої інформаційної системи управління використовується корпоративна система, яка дозволяє: узагальнити інформаційні потоки; класифікувати всю інформацію; забезпечити доступ до центральних баз даних; забезпечити обмін інформацією. Усе це дозволяє забезпечити працівникам системи управління освітою доступ до якісно нового рівня інформатизації та дозволяє підвищити ефективність роботи.

Сучасні інформаційні технології $є$ основою процесу інформатизації освіти, реалізація якого припускає, в тому числі, i:

- інтеграцію різних видів діяльності (навчальної, навчально-дослідницької, методичної, наукової, організаційної) у рамках єдиної методології, розробленої на застосуванні інформаційних технологій;

- підготовку учасників освітнього процесу до життедіяльності в умовах інформаційного суспільства;

- підвищення професійної компетентності і конкурентноздатності майбутніх фахівців різних галузей;

- подолання кризових явищ у системі освіти [4].

Однією 3 найважливіших задач інформатизації освіти $є$ формування інформаційної культури фахівця, рівень сформованості якої визначається, по-перше, знаннями про інформацію, інформаційні процеси, моделі та технології; по-друге, уміннями і навичками застосування засобів і методів оброблення й аналізу інформації в різних видах діяльності; потретє, умінням використовувати сучасні інформаційні технології у професійній (освітній) діяльності; по-четверте, світоглядним баченням навколишнього світу як відкритої інформаційної системи. 
У сучасних умовах інформатизації суспільства, розвитку комп’ютерних мереж, засобів телекомунікацій професійна інформаційна сфера вимагає підготовки фахівців 3 управління інформаційними потоками підприємств та організацій (як внутрішніми, так і зовнішніми) 3 використанням комп'ютерних інформаційних систем - менеджерів інформаційних систем.

Концептуальні підходи до підготовки менеджерів інформаційних систем базуються на результатах вивчення та прогнозування структури соціальної та виробничої діяльності фахівців 3 вищою освітою в галузі інформаційної діяльності відповідно до потреб ринку праці, на відповідних вимогах до фахівця, згідно з якими визначається зміст освіти в окресленій галузі, тобто концепція підготовки менеджерів інформаційних систем базується на розробленні моделі спеціаліста, основою побудови якої є система: «суспільна потреба - освітньо-професійна програма (знання) - освітньо-кваліфікаційна характеристика (уміння) - засоби діагностування у взаємозв'язку і взаємозумовленості всіх іï компонентів, поєднанні 3 визначенням педагогічних умов підготовки фахівців та відповідних практичних підходів до їх реалізації [2].

Метою багатьох програм з інформатизації освіти є створення єдиного інформаційноосвітнього середовища. Управління навчальним закладом в цьому разі посідає головне місце і $€$ центром реалізації окресленої мети. Сдине інформаційно-освітнє середовище - реальність, яка організована та управляється єдиною концепцією, підходами та механізмами реалізації загальної стратегії формування, розвитку та досягнення цілей підвищення культурного, освітнього та професійного рівнів суб'єктів, що об'єднані на єдиній інформаційнотехнологічній основі для підтримки суб'єктів виокремленого середовища.

Єдине інформаційно-освітнє середовище можна розглядати в кількох аспектах, одним із яких $є$ управлінський. За характером управління- це створення єдиної багаторівневої ієрархічної системи організації і управління освітнім середовищем.

Нині інформатизація освіти підпорядкована головній меті впровадження інформаційних технологій - створення єдиного інформаційного простору освітньої установи. Це система, у якій задіяні та на інформаційному рівні перебувають у тісному взаємозв'язку всі учасники навчального процесу: адміністратори, викладачі, учні і їхні батьки.

Єдиний інформаційний простір трактується як сукупність взаємопов'язаних компонентів:

- інформаційних ресурсів, що містять дані, відомості і знання, зафіксовані на відповідних носіях інформації;

- організаційних структур, що забезпечують функціонування та розвиток єдиного інформаційного простору, зокрема, збір, оброблення, зберігання, поширення, пошук i передавання інформації;

- засобів інформаційної взаємодії громадян й організацій, що забезпечують їм доступ до інформаційних ресурсів на основі відповідних інформаційних технологій - програмнотехнічних засобів й організаційно-нормативних документів [1].

Сдиний інформаційний простір навчального закладу повинен бути підпорядкованим освітньому процесу, забезпечувати й обслуговувати, у першу чергу, освітню діяльність закладу і як її необхідна умова - управлінську.

Для того щоб поняття єдиного інформаційного простору стало доступним, а завдання й принципи його формування актуальними для конкретних навчальних закладів й органів управління освітою, необхідно розглянути його структуру й інформаційні рівні, визначити коло учасників і ступінь їхньої зацікавленості, а також форми взаємодії як усередині, так і за межами інформаційного поля освітньої установи. Під учасниками навчально-виховного процесу, які входять безпосередньо до процесу створення i функціонування єдиного інформаційного простору, варто розуміти такі стійкі групи: адміністрація навчального закладу, вчителі, учні, батьки. Практично всі учасники навчально-виховного процесу об'єднані між собою відповідними інформаційними потоками. Побудова єдиного освітнього простору на першому етапі зводиться, по суті своєї, до створення загальної інформаційної бази даних, тобто комп'ютерного відображення інформаційного поля навчального закладу, що поєднує формалізовані потоки, та організації постійного доступу до неї всіх учасників навчальновиховного процесу.

Загальна база даних навчального закладу або базовий інформаційний простір, як ядро єдиного інформаційного простору, повинна дотримуватись та надавати можливість відновлення подальшої інформації: загальної інформації про навчальний заклад; кадрові данні 
про педагогів і особисті дані про учнів; формалізованих інформаційних блоків: навчального плану, штатного розпису, матеріально-технічної бази тощо. Для того щоб залучити до процесу інформатизації якомога більше число учасників i зробити його для них максимально змістовним i необхідним (тобто мотивованим), необхідно доповнити загальну базу конкретними додатками, які повинні створюватися для розв'язання найбільш складних проблем навчального закладу, «некомп'ютерне» рішення яких $\epsilon$ більш важким й малоефективним. До подібним додатків можна віднести такі модулі, як: «Розклад», «Кадри», «Тарифікація», «Бухгалтерія», «Клас (класний керівник і класний журнал)», «Успішність», «Урок» тощо. Значимість даних додатків беззаперечно зростає, якщо враховувати, що й саме створення єдиного інформаційного простору достатньо складний процес.

Сдиний інформаційний простір навчального закладу виконує інформаційну, освітню й комунікативну функції за рахунок наявності єдиної для всього закладу бази даних, що містить інформацію про різні аспекти навчально-виховного процесу (відомості про співробітників, учнів і батьків, навчальний план, електронний класний журнал, розклад, різноманітні звіти та т.п.); наявності в користувачів можливості спілкування між собою (за допомогою внутрішньошкільної дошки оголошень і внутрішньошкільної пошти) та доступу до загальних ресурсів; використання у навчальному процесі різноманітних IT курсів, а також інтегрування всіх курсів до єдиного середовища; наявності єдиного простору, у якому співробітники закладу й учні оволодівають інформаційно-комунікаційними технологіями [1].

Без особистого бажання й волі керівника навчального закладу інформатизація закладу унеможливлює провал. Керівник повинен стати головним ініціатором і розпорядником цього процесу. У процесі інформатизації закладу необхідно перебороти труднощі як технічного, так і психологічного порядку: невміння й острах рядових співробітників щоденно користуватися комп'ютерною технікою, відсутність мотивації змінити звичні паперові технології роботи на інформаційно-комп'ютерні тощо.

Прикладом взаємодії органів місцевого самоврядування, відділів освіти й навчальних закладів $є$ інформаційний експеримент ICOУ. Сумщина стала пілотною у реалізації розглянутого Всеукраїнського інформаційного експерименту «Інформаційна система управління освіти» $(2010$ - 2014 р.p.): Тростянецький районний відділ освіти, який, отримавши перемогу у Всеукраїнському конкурсі інвестиційних проектів (2010р.), відкрив інформаційнометодичний центр (2011р.), як осередок інформатизації освіти в районі, в 2011 р. був залучений до Всеукраїнського експерименту із запровадження інформаційної системи управління освітою. Так, до єдиної інформаційної системи району підключено 19 навчальних закладів району, що складає 3,5\% від загальної кількості ЗНЗ області (в середньому по Україні - 2,8 \%). Результатом експериментальної роботи став Портал «Сумська обласна освітня мережа: Шкільна мережа», який являє собою головну частину інформаційної системи «КУРС: Освіта» $\mathrm{i}$ включає набір засобів та інструментів, призначених для автоматизації управлінської діяльності адміністрацій загальноосвітніх навчальних закладів регіону, управлінь і відділів освіти рай/міськдержадміністрацій, обласного управління освіти і науки облдержадміністрації. Комплекс дозволив створити єдину систему збору, оброблення та зберігання інформації Сумської області в розрізі закладів загальної середньої освіти. Одночасно розв'язується проблема забезпечення районних, міських відділів/управлінь освіти та обласного управління освіти і науки повною оперативною інформацією про діяльність загальноосвітніх навчальних закладів, що надасть змогу здійснювати освітній менеджмент на більш високому рівні, ефективніше планувати витрати міських та районних бюджетів в рамках реалізації освітянських програм, раціонально й обгрунтовано корегувати напрями для подальшого розвитку освіти Сумщини, а з іншого боку, - забезпечувати відповідний рівень контролю за діяльністю навчальних закладів регіону.

Отже, зрозуміло, що не можна досягти модернізації навчально-виховного процесу без модернізації системи управління навчальним закладом. Для ефективної модернізації управління та оновлення технічного арсеналу засобів управління необхідно оптимізувати реалізацію державних програм, спрямованих на інформатизацію, комп'ютеризацію та оновлення матеріально-технічної бази навчальних закладів. Підготовка всіх учасників навчально-виховного процесу до сучасного управління навчальним закладом за допомогою інформаційнокомунікаційних технологій є дієвим складником ефективного освітнього менеджменту. 


\section{Література}

1. Базовая ИКТ компетенция как основа Интернет-образования учителя: Тезисы доклада А.А. Елизарова на конференции RELARN-2004 июнь 2004 г. - Ассоциация RELARN - Режим доступа: http://www.relarn.ru/conf/conf2004/section3/3_11.html. 2. Громов Г. Р. Очерки информационных технологий / Г.Р. Громов. - М.: ИнфоАрт, 2002.-336 с. 3. Доповідь про стан та розвиток інформатизації в Україні за 2009 рік // Кабінет Міністрів України. - К., 2009. [Електронний ресурс] / Сайт «Законодавство України» - Режим доступу: http://zakon.rada.gov.ua/cgi-bin/ laws/ main. cgi? nreg $=$ n000512009 \&test =4/ UMfPEG znhhx Pk.ZiTCXiquHdlhss FggkRbI1c 4. Енциклопедія освіти / гол. ред. В.Г.Кремень; Акад. пед. наук України. - К.: Юрінком Інтер, 2008. - 1040 с. 5. Жук Ю. О. Системні особливості освітнього середовища як об’єкту інформатизації / Ю. О. Жук // Післядипломна освіта в Україні. - 2002. - № 2. - С. 35-37. 6. Забродська Л. М. Інформаційнокомунікаційні технології управління сучасним закладом освіти / Л. М. Забродська, Є. Р. Чернишова // Освіта й управління. - 2002. -№ 2. - С. 108-116. 7. Закон України Про Концепцію Національної програми інформатизації [Електронний ресурс] / Сайт «Законодавство України» - Режим доступу: http://zakon2.rada.gov.ua/laws/show/75/98-вp 8. Олешко О. В. Якість освіти - основа інформаційного суспільства / О. В. Олешко // Державне будівництво. - 2009. - №1. 9. Свободнова Н. Інноваційне управління навчальним закладом / Н. Свободнова // Персонал. - 2006. - №11.

\section{ОСУЩЕСТВЛЕНИЕ ПОДГОТОВКИ БУДУЩИХ ВОСПИТАТЕЛЕЙ К ПРОЦЕССУ ФИЗИЧЕСКОГО ВОСПИТАНИЯ И РАЗВИТИЯ ДЕТЕЙ В УСЛОВИЯХ ДОШКОЛЬНОГО УЧРЕЖДЕНИЯ}

Любашина В. В. Здійснення підготовки майбутніх вихователів до процесу фізичного виховання і розвитку дітей в умовах дошкільного закладу.

Творчий вихователь не подає дітям матеріал, не цікавий йому самому, прагнучи віднайти в ньому дивовижне, незвичайне і захоплююче. Використання вихователями нетрадиційних методів фізичного виховання і розвитку дітей в умовах дошкільного закладу допоможе оптимізувати й урізноманітнити процес фізичної освіти і валеологічного виховання, так само підвищити рівень своєї педагогічної майстерності.

Ключові слова: фізичне виховання, фізичний розвиток, валеологічне виховання, фізична освіта.

Любашина В. В. Осуществление подготовки будущих воспитателей к процессу физического воспитания и развития детей в условиях дошкольного учреждения.

Творческий воспитатель не преподносит детям материал, который не интересен ему самому, стремясь найти во нём удивительное, необыкновенное и увлекательное. Использование воспитателями нетрадиционных методов физического воспитания и развития детей в условиях дошкольного учреждения поможет оптимизировать и разнообразить процесс физического образования и валеологического воспитания, а так же повысить уровень своего педагогического мастерства.

Ключевые слова: физическое воспитание, физическое развитие, валеологическое воспитание, физическое образование.

Lyubashina V. V. Implementation of the training of future teachers in the process of physical education and development of children in preschool.

Creative teacher does not present material to children which is not interested to herself / himself, trying to find all the surprising, unusual and fascinating. The use of non-traditional teachers methods of physical education and development of children in preschool will help diversify and optimize the process of physical education and valeological education, as well as to improve their teaching skills.

Keywords: physical education, physical development, valeological education, physical education.

В настоящее время большую тревогу вызывают сведения медиков и педагогов об ухудшающемся состоянии здоровья детей дошкольного возраста. Прогрессирует нарушение экологического равновесия, негативно влияют на здоровье детей различные факторы внешней 